\title{
AN INVESTIGATION OF INCOME AND SUBSTITUTION EFFECTS ON FEMALE LABOUR SUPPLY THROUGH A CHAID ANALYSIS: THE SERVICE SECTOR CASE SPECIFIC TO THE TR51 REGION
}

\author{
Dr. Lecturer Kübra ÖNDER \\ Mehmet Akif Ersoy University, FEAS, Burdur, Turkey (konder@mehmetakif.edu.tr) \\ Dr. Lecturer Işıl ALKAN \\ Ondokuz Mayıs University, FEAS, Samsun, Turkey (isilalkan@omu.edu.tr)
}

\begin{abstract}
The aim of this study is to investigate factors affecting female labour supply and to study income effect and substitution effect which have a micro-economic significance for female labour supply in the factor market. To this end, the study used the data obtained from the TURKSTAT Household Labour Force Survey 2016 and performed a chi-squared automatic interaction detection (CHAID) analysis. The analysis results showed that working time in main job, working type, educational level, workplace, household income and social security are the most significant factors of the decision-making of single and married women who supply labour in the service sector.
\end{abstract}

Anahtar Kelimeler: Income Effect, Substitution Effect, Labour Market, CHAID Analysis.

\section{KADIN EMEK ARZI ÜZERINDEKİ GELİR VE İKAME ETKİSININ CHAID ANALIZİ İLE İNCELENMESİ: TR51 BÖLGESİ HIZMET SEKTÖRÜ ÖRNEĞİ}

\begin{abstract}
ÖZET
Bu çalışmanın amacı, kadın emek arzını etkileyen faktörleri araştırmak ve emek faktör piyasasında mikro boyutta önemli olan gelir ve ikame etkisinin kadın emek arzındaki yerini incelemektir. Bu amaçla 2016 yılına ait Hanehalkı Issgücü Anketlerinden elde edilen veriler kullanılmıştır. Uygulamada CHAID analizinden yararlanılmıştır. Analiz sonuçları; hizmet sektöründe emek arz eden bekâr ve evli kadınların emek arzı kararında esas işte çalışılan sürenin, çalışma şeklinin, ĕgitim düzeyinin, çalışılan yerin, hanehalkı gelirinin ve sosyal güvencenin en önemli faktör olduğunu göstermektedir.
\end{abstract}

Keywords: Gelir Etkisi, İkame Etkisi, Issgücü Piyasası, CHAID Analizi. 


\section{Introduction}

Female labour supply is a sophisticated concept influenced by many determinants such as marital status, fertility, and educational level. In other words, it is distinct from male labour supply. Despite the significant progress in female labour force participation globally, gender gaps still remain high in many regions. From a sectoral perspective, the service sector is the main sector employing women on a large scale in the world over the last decades. The situation in Turkey is similar to the global picture as the service sector employed $56 \%$ of the employed women in the country in 2016 (TURKSTAT, 2017). It is worth noting that not only is female labour participation in Turkey lower than the world average but also it has the lowest female labour supply rate among OECD countries in 2016 (OECD, 2017).

Labour supply is an important component of labour markets; income and substitution effects are the main factors regarding individual labour supply according to neoclassical economics (Cahuc \& Zylberberg, 2001:5-9). The literature includes research investigating factors affecting labour supply but lacks a sector-based analysis of substitution and income effects and gender (Ashenfelter \& Heckman, 1974; Killingsworth \& Heckman, 1986; Kimball $\&$ Shapiro, 2008). Additionally, studies analyzing substitution and income effects are far from a sectoral dissection. Therefore, this study is a precursor in that it analyses factors affecting labour supply by gender on a sectoral basis. Accordingly, the aim of this study is to find out whether the determinant factors regarding labour supply vary by gender at the sectoral level. To this end, the study used the household labour force survey carried out by the Turkish Statistical Institute (TURKSTAT) in 2016 and selected the TR51 (Ankara) region at the level of Nomenclature of Territorial Units for Statistics (NUTS) 2. The study consists of five sections. The first section includes an overview of female participation in labour markets. The second section deals with the determinants of female labour supply. The third section explains the dataset and methods. The fourth section presents the analysis results. The final section includes a discussion of the results and concluding remarks.

\section{An Overview of Female Participation in Labour Markets}

Although women make up nearly half of the world population, their access to labour markets is limited compared to men. Gender gaps in employment have been prevalent in almost all countries. The average labour force participation rate was $76.1 \%$ for men and $49.5 \%$ for women in the world in 2016. Thus, while the global gender gap in labour force participation was $26.6 \%$ in 2016, the gap varies according to regions in the world. Although there has been an increasing representation of women in the global labour force over the last decades, some regions have a different experience of the situation. The International Labour Organization (ILO) data asserts that the female labour supply rate is the highest in Northern European countries (especially in the Nordic countries) while it is the lowest in the Arab states, Northern Africa, and Southern Asia (KILM, 2017). Additionally, part-time work and vulnerable employment are the specific features of female employment worldwide. Due to heavy household and care responsibilities, women face challenges in finding invulnerable and full-time jobs.

Regrettably, Turkey is one of the nations having the lowest female labour force participation (FLFP) rate and the lowest female labour supply rate among OECD countries. In 2016, the FLFP rate was $63.6 \%$ in the OECD average while it was $36.2 \%$ for Turkey (OECD, 
2017). The low FLFP in Turkey is closely related with socio-economic transformations in the last decades. Agricultural dissolution and urbanization caused the exclusion of women from labour markets due to insufficient working opportunities in the service and industry sectors. Thus, female unemployment and the low female labour supply have become a reality for urban areas. Compared to rural areas, FLFP is very low in urban Turkey because a large number of women are still employed in agriculture in rural areas. Although women generally work as unpaid family workers in subsistence agriculture, the participation rate of rural women is relatively higher than the urban women in the country. According to the 2013 statistics, the FLFP rate in urban Turkey was $28 \%$ while it was $37 \%$ in rural Turkey (TURKSTAT, 2017).

\section{Determinants of Female Labour Supply}

Considering labour supply theories, the mainstream (neoclassical) theory of labour supply is a model based on a trade-off between consumption and leisure. In the neoclassical theory of labour supply, labour supply increases when wages are low and decreases when wages are sufficiently high. Substitution effects and income effects are the main factors of individual labour supply (Cahuc \& Zylberberg, 2001:5-9). The substitution effect refers to the fact that a rise in real wages increases the opportunity cost of leisure; thus higher wages will generally cause people to work longer hours. In this regard, the substitution effect is a positive effect. On the other hand, the income effect refers to individual preferences for working less in response to a change in the wage as the wage rate increases and a certain amount of income can be obtained by working less. If the income effect is dominant, a labour supply curve shifts leftwards after a certain wage level and is negatively sloped (bent backwards). However, empirical studies support the view that if the substitution effect is more dominant, a labour supply curve is positively sloped (Yıldırım et al., 2010:125). On the other hand, female labour supply is a complex concept different from the usual labour supply theory as the determinants of female labour supply are various and variable.

The determinants of FLFP are various and changeable on a country basis. The literature reports educational level, fertility rate, social and cultural structure, the development level of the country, labour laws as the outstanding determinants of female participation in labour markets. Studies confirming the abovementioned determinants are as follows: Research on the determinants of female labour force participation in OECD countries revealed that tax incentives, child care subsidies, and paid maternity and parental leaves have a positive impact on female participation. However, unlike childcare subsidies, child benefits decrease female participation due to an income effect and their lump-sum character. Female education, general labour market conditions and cultural attitudes are the major determinants of female participation (Jaumotte, 2003:2). Taşseven et al. (2016:27) argued that educational attainment, fertility, unemployment rate, gross domestic product (GDP) per capita were the major determinants affecting the FLFP rate in OECD countries between 1990 and 2013 whereas the fertility rate was the most influential one. Sorsa et al. (2015:3) found that social and cultural factors, lack of jobs, infrastructure, access to finance, and labour laws are the main determinants of the low female labour force participation in India. Spierings et al. (2008:2-26) discussed that economic need, educational level, husband's socio-economic status, and traditional values and norms are the main factors shaping women's employment opportunities in six Middle East and North Africa (MENA) countries including Algeria, Egypt, Jordan, Morocco, Syria and Tunisia. However, among these 
components, women's educational level is emphasized as the key determinant of employment in the MENA region. Cipollone et al. (2012:1-48) reported that marital status, number of children and education were the important determinants of the female labour market status in Europe between 1994-2009. They further discussed that institutional and policy changes affected the labour market opportunities of women in the region for the same period. Yakubu (2010:85101) emphasized age, marital status, fertility, migration as the key factors affecting FLFP in South Africa in 2008 and further suggested a strong correlation between educational level and FLFP in the region. Gift (2013) argued that high economic performance, high educational levels for females and high male unemployment rates are the basic determinants of FLFP in Zimbabwe for the period between 1980 and 2012. Shi (2016:1-17) reported that age, marital status, educational level, the presence of a young child (under school age) and location (urban/ rural) are the key drivers of FLFP in China. On the other hand, high levels of education increase the probability of labour market participation more significantly in urban areas. Chamlou et al. (2011) showed that higher education (post-secondary/university/post-university) has a positive and significant impact on FLFP, whereas secondary education and below do not in Amman, Jordan (as a representative city in MENA). In addition, there is a strong negative statistically significant association between traditional social norms and women's participation of women in labour force. Dayığlu \& Kirdar (2010:1-54) reported schooling, age, marital status and the number of children as the main determinants of FLFP in Turkey.

Ince \& Demir (2006:85) investigated the determinants of female labour force in Turkey by using time series regression and revealed that education level, GDP growth rate, fertility and unemployment rate impacts female labour force participation in the country. Er (2013:35) examined factors affecting the labour participation rates of females in Turkey in her research and found that the education levels, men's participation rates, women's participation in agricultural sector have a significant positive effect and fertility rates have a negative significant effect in 2010 NUTS-2 level geographical data, while the population growth rate has no significant effect. Ayvaz- Kızılgöl (2012:88) researched factors impacting the women's decision of working in Turkey by logit model analysis and asserted that education level, household income, dependency ratio, ownership of the property and women's age are the most important factors as to the women's decision of participating to labour force regarding the married and single women. Furthermore, the number of children reduces the labour force participation in urban areas while increases in rural areas. Tansel (2002), emphasized that growth rate and level of education have positive effects on female labour participation in her study by using time series evidences in 67 provinces in Turkey. Moreover, she found that unemployment had a considerable discouraging effect on female labor force participation. Akgeyik (2017:32) examined the factors that affect labor force participation of women in Turkey between 2007 and 2016 and executed that the main factor affecting female participation rate is the increased education level of women. Moreover, increasing marriage age for women influences female labor force participation. Furthermore a declining fertility also increases the participation rate among women. Uysal et al. (2016:88) examined factors determining female labour force participation in Turkey by the help of Vector Auto Regression (var) Model and unearthed that GDP and level of education affects female labour force participation in the country. Tunalı \& Göksu (2018:29) revealed that the most effective determinants of women's participation in labor force is education and there is an inverse relationship between age and female labor force participation. Additionally, the 
marital status of women, the place they live in (rural-urban) and the proximity of the reference person affect the probability of their participation in the workforce.

According to Mincer's work on labour supply of married women, "wives' labour force participation rates respond negatively to husband's incomes: the more husbands earn, the less wives work, [while] wives' labour force participation rates respond positively to wives' earning power: the more the wife is capable of earning, the more likely she is to work". Additionally, wives are more likely to work if husbands' current earnings were below permanent earnings (Mincer, 1962:101). Ettner (1995:76) argued that co-residence with a disabled parent has a large and significant negative effect on female labour supply and this effect mostly results from nonparticipation in the labour force rather than from a reduction in hours among workers. Cruces \& Galiani (2007) studied the effect of fertility on maternal labour supply in Latin America and found that having more than two children reduces mother's labour supply by about 8.1-9.6 percentage points in Argentina and by about 6.3-8.6 percentage points in Mexico. Buchmueller \& Valletta (1999) analysed the effects of employer-provided health insurance on the labour supply of married women in the United States. They found a strong negative effect of husbands' health insurance on wives' work hours, particularly in families with children. Eckstein \& Lifshitz (2011) estimated a female dynamic labour supply model and showed that the rise in educational levels accounts for about 33 per cent of the increase in female employment, and the rise in wages and narrowing of the gender wage gap account for another 20 per cent, while about 40 per cent remains unexplained by observed household characteristics in the United States. Bloom et al. (2009) focused on the effect of fertility reduction on female labour force participation. They used a panel of 97 countries over the period 1960-2000 to investigate the effect of fertility on female labour force participation during their fertile years. They found that each birth reduces a woman's labour supply by almost two years during her reproductive life. Blau \& Kahn (2013) reported that the expansion of "family-friendly" policies, including parental leave and part-time work entitlements in various OECD countries have positive effects on female labour force participation. In other words, there is a tradeoff between some policies and female labour force participation in economically advanced countries. Cerrutti (2000) argued that economic uncertainty is an important determinant of female labour force participation. Using cross-sectional and panel data, the author showed that most of the growth in FLFP can be explained as a response to increasing unemployment and job instability associated with the implementation of structural adjustment policies since 1991 in Argentina. Cerrutti further underscored that more women decided to look for a job to reduce households' economic uncertainty. Similarly, Attanasio et al. (2005) explored the role of female labour supply as an insurance mechanism against idiosyncratic earnings risk within the family. They found that additional uncertainty increases female participation rates, especially when the ability to borrow within a family is limited.

\section{Data Set and Methods}

\subsection{Data Set}

This study used the 2016 Household Labour Force Survey statistics (Group B microdata set) of TURKSTAT to analyse factors affecting female labour supply within the framework of the service sector. The service sectors from 55 to 99 codes according to the NACE Rev. 2 
statistical classification of economic activities were included in the model. The TR51 (Ankara) region at the level of NUTS-2 was used as a sample on account of the volume of B microdata. Active female population (15-65 aged) was included in the analysis. The dependent variable is female labour supply in the service sector. The independent variables include income, household size, educational level, marital status, age, the number of years worked, working time in main job, working type, the existence of a second job, working time in second job, the reason for seeking a second job, the existence of social security, and workplace. The model was analysed through SPSS 24 software using the CHAID algorithm.

\subsection{Methods}

Data mining dates back to the time when the analysis problems of sizeable data stacks were solved by computers in the 1960s. Data mining refers to the entire work aiming to extract meaningful data from the unstructured data available. This process is carried out through the selection of suitable modelling technique (Seifert, 2004:4; Özekes, 2003:67). Models used in data mining are classified into two categories as predictive and descriptive. The study performed a CHAID analysis which is a decision tree method used for predictive data mining. The decision tree method is exempt from the assumptions of regression analysis although it resembles regression analysis due to its non-parametric nature (Nisbet et al., 2009; Chang \& Man Law, 2008; Yohannes \& Webb, 1999). A regression analysis benefits from in-group variables; thus, it remains weak in reflecting intergroup differences. It is asserted that the decision tree method can be used to overcome this problem (Assael, 1970). Additionally, the decision tree method is more successful in short-term estimates compared to the regression analysis method (Chen, 2011). Decision trees are preferred in many areas as they are coherent, easily interpreted and reliable and offer graphical findings (Gorunescu, 2001, Argüden \& Y1lmaz, 2008:47; Ritschard, 2013). Each branch of a tree represents a classification problem and leaves (nodes) are parts of data set regarding the classification. With a strong iteration algorithm, decision trees do not require normality and homogeneity assumptions of data (Kayri \& Boysan, 2007). Decision trees also insert all independent variables for an identified dependent variable and all their combinations into the model, thereby guaranteeing the truest classification. Additionally, they are not affected by missing or extreme values which can occur in both dependent and independent variables (Wilkinson, 1979).

The algorithms used for the classification in decision trees include CHAID, C4.5, CART, ID3, SLIQ, SPRINT, and QUEST. Although decision tree algorithms have different operation categories they mainly aim to find a statistically significant model and separate the data set of a categorical variable into homogeneous subgroups in such a way that it best explains the dependent variable (Gorunescu, 2011). To put it most succinctly, decision tree algorithms consist of three stages. First, the stage of "constitution of tree" involves composing homogeneous subgroups at the maximum level. Second, the selection of tree which best explains the dependent variable resembles "tree pruning". Following the pruning stage, the operation is completed with the "selection of the most suitable tree structure" (Breiman et al., 1984).

CHAID is the most preferred method among decision tree algorithms. It is more commonly used as it offers more opportunities and advantages than others. Additionally, it 
does not require normality and homogeneity assumptions of data as it has a strong iteration algorithm (Kayri \& Boysan, 2007; Üngüren \& Doğan, 2010). The CHAID algorithm, originally proposed by Kass (1980) and developed by Jay Magidson (1993), generally has a dependent variable $d \geq 2$ and an independent variable $c \geq 2$. The sub-problem of the analysis is to degrade dimensional possibility table to the most significant cxd dimensional estimator by combining similar categories of the independent variable. For this purpose, first, $T_{j}^{(i)}$ statistics is calculated. $T_{j}^{(i)}$ is the usual $X^{2}$ statistics for the $i$ th method of forming a jxd table $\left(j=2,3, \ldots, c\right.$; the range of $i$ depending on the type of the predictor). If $T_{j}^{(*)}=\max _{i} T_{j}^{(i)}$ is the $X^{2}$ statistics for the best jxd table, the most significant $T_{j}^{*}$ is chosen (Kass, 1980:120). The five steps of determining $T_{j}^{*}$ are presented below:

Step 1. For each predictor in turn, cross-tabulate the categories of the predictor with the categories of the dependent variable and do steps 2 and 3.

Step 2. Find the pair of categories of the predictor (only considering allowable pairs as determined by the type of the predictor) whose $2 \times d$ sub-table is least significantly different. If this significance does not reach a critical value, merge the two categories, consider this merger as a single compound category, and repeat this step.

Step 3. For each compound category consisting of three or more of the original categories, find the most significant binary split (constrained by the type of the predictor) into which the merger may be resolved. If the significance is beyond a critical value, implement the split and return to step 2.

Step 4. Calculate the significance [...] of each optimally merged predictor and isolate the most significant one. If this significance is greater than a criterion value, subdivide the data according to the (merged) categories of the chosen predictor.

Step 5. For each partition of the data that has not yet been analysed, return to step 1. This step may be modified by excluding from further analysis partitions with a small number of observations (Kass, 1980:121).

Accordingly, a CHAID analysis segregates the data set of categorical variables and dependent variable into sub-levels. The significant variables in sub-levels proceed by separating into new subsets (Conover, 1971; Kass, 1980). This process continues until a point where it is impossible to do more combinations. The convenience of variables for division is decided by Bonferroni adjusted p-values (Ritschard, 1998). The Bonferroni approach depends on difference values, whether they are zero or not, following the calculation of difference of each group's average vectors from the general average vector. After determining the best division for each explanatory variable which gathers the categories in the most significant way, a contingency table is created according to the explained variable. The Bonferroni multiplier is calculated using the formula in Equation 1 if the categories of an explanatory variable are nominal; it is calculated using the formula in Equation 2 if the categories of an explanatory variable are on an ordinal scale. 


$$
\begin{aligned}
& B_{\text {free }}=\sum_{i=0}^{r-1}(-1)^{i} \frac{(r-i)^{c}}{i !(r-i) !} \\
& B_{\text {monotonic }}=\frac{(c-1)}{(r-1)}
\end{aligned}
$$

In Equations 1 and 2, $c$ refers to category number and $r$ refers to group numbers of an explanatory variable as $1 \leq r \leq c$. The $X^{2}$ statistics (or $\mathrm{F}$ test is used) is calculated using Bonferroni p-values. Explanatory values are compared to each other and data are reseparated into subgroups according to the categories of an explanatory variable with the lowest Bonferroni p-value; thus, the best division for an explanatory variable is found. The selected explanatory variables are compared again and divisions for the best explanatory variable is achieved (Kass, 1980:122).

\section{Analysis Results}

The factors affection female labour supply in the labour market was analysed using a CHAID analysis. First, the dependent and independent variables were determined to establish the model. Later, the results of the CHAID analysis were presented. The dependent and independent variables for establishing the model are described in Table 1.

\begin{tabular}{|c|c|c|c|}
\hline Dependent Variable in the Study & & f & $\%$ \\
\hline \multirow{2}{*}{ Employment status } & Yes & 2734 & 92.4 \\
\hline & No & 224 & 7.6 \\
\hline \multicolumn{4}{|l|}{ Independent Variables in the Study } \\
\hline \multirow{5}{*}{ Income } & 1500 and under & 1621 & 54.8 \\
\hline & Between 1501 and 3000 & 843 & 28.5 \\
\hline & Between 3001 and 4500 & 364 & 12.3 \\
\hline & Between 4501 and 6000 & 80 & 2.7 \\
\hline & 6001 and over & 50 & 1.7 \\
\hline \multirow{3}{*}{ Household size } & 2 and under & 717 & 24.2 \\
\hline & Between 3 and 5 people & 2079 & 70.3 \\
\hline & 6 and over & 162 & 5.5 \\
\hline \multirow{4}{*}{ Education } & $\begin{array}{c}\text { Illiterate and primary school } \\
\text { (8 years) }\end{array}$ & 954 & 32.3 \\
\hline & High school & 568 & 19.2 \\
\hline & University & 1169 & 39.5 \\
\hline & Master or PhD. & 267 & 9.0 \\
\hline
\end{tabular}

Table 1. The Dependent and Independent Variables for Establishing the Model 
Table 1 continue

\begin{tabular}{|c|c|c|c|}
\hline \multirow{3}{*}{ Marital status } & Single & 734 & 24.8 \\
\hline & Married & 1911 & 64.6 \\
\hline & Widow & 313 & 10.6 \\
\hline \multirow{5}{*}{ Age } & Between 15-24 & 357 & 12.1 \\
\hline & Between 25-35 & 883 & 29.9 \\
\hline & Between 36-45 & 952 & 32.2 \\
\hline & Between 46-55 & 544 & 18.4 \\
\hline & 56 and over & 225 & 7.5 \\
\hline \multirow{5}{*}{ Number of years worked } & 5 and under & 1567 & 53.0 \\
\hline & Between 6-10 & 786 & 26.6 \\
\hline & Between 11-20 & 440 & 14.9 \\
\hline & Between 21-30 & 123 & 4.2 \\
\hline & 31 and over & 42 & 1.4 \\
\hline \multirow{5}{*}{ Working time in main job } & 20 hours and under & 533 & 18 \\
\hline & Between 21-40 hours & 1379 & 46.6 \\
\hline & Between 41-60 hours & 962 & 32.5 \\
\hline & Between $61-80$ hours & 74 & 2.5 \\
\hline & 81 hours and over & 10 & 0.3 \\
\hline \multirow{2}{*}{ Working type } & Full-time & 2371 & 80.2 \\
\hline & Part-time & 587 & 19.8 \\
\hline \multirow{2}{*}{ Existence of a second job } & Existing & 19 & 0.6 \\
\hline & Non-existing & 2939 & 98.6 \\
\hline \multirow{3}{*}{ Working time in second job } & 10 hours and under & 2939 & 98.6 \\
\hline & Between 11-20 hours & 15 & 0.5 \\
\hline & 21 hours and over & 4 & 0.1 \\
\hline \multirow{4}{*}{ Reason for seeking a second job } & Earning more income & 245 & 8.2 \\
\hline & Working less & 2 & 0.1 \\
\hline & Other & 4 & 0.1 \\
\hline & Not seeking a second job & 2705 & 90.8 \\
\hline \multirow{2}{*}{ Existence of social security } & Existing & 2325 & 78.6 \\
\hline & Non-existing & 633 & 21.4 \\
\hline \multirow{3}{*}{ Workplace } & Government sector & 2016 & 68.2 \\
\hline & Private sector & 881 & 29.8 \\
\hline & Other & 61 & 2.1 \\
\hline
\end{tabular}


The labour of women engaged in the service sector was classified as working and nonworking categories; a CHAID analysis was performed to examine the income and leisure time variables affecting female labour supply in addition to other factors used in the literature. Total household income, working time in main job, working time in second job, and the reason for seeking a second job were included in the model to analyse income and substitution effects. Figure 1 shows the tree diagram obtained from the analysis of the model. As seen in Figure 1, seven branches and twelve nodes were obtained.

\section{Figure 1. Tree Diagram Obtained through the CHAID Analysis}

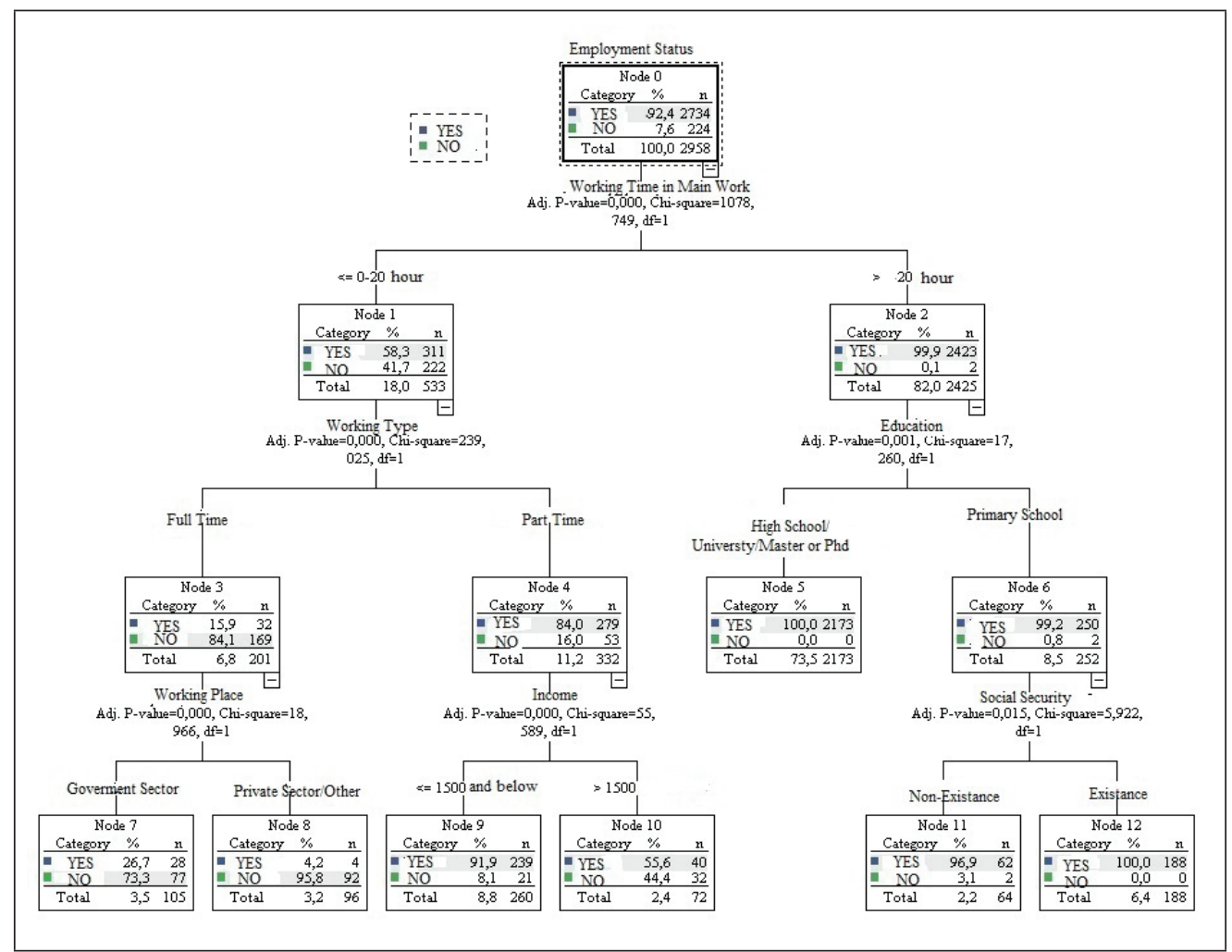

Given the tree diagram above, female labour in the service sector is affected by working time in main job, working type, education, workplace, income, and social security. Each branch and node in Figure 1 are discussed in detail in the study. The dependent variable female labour supply is available in the first node of the CHAID analysis. Accordingly, $92.4 \%$ of employed women want to supply their labour, while the remaining $7.6 \%$ do not want to participate in labour.

The analysis results revealed that the most important variable affecting the dependent variable is working time in main job $(=1078.749,=0.000,=1)$. This variable is divided into two sub-categories, namely two nodes (those working more than 20 hours and those working 20 hours or less). 
Figure 2. The First Branching that Occurred After the CHAID Analysis

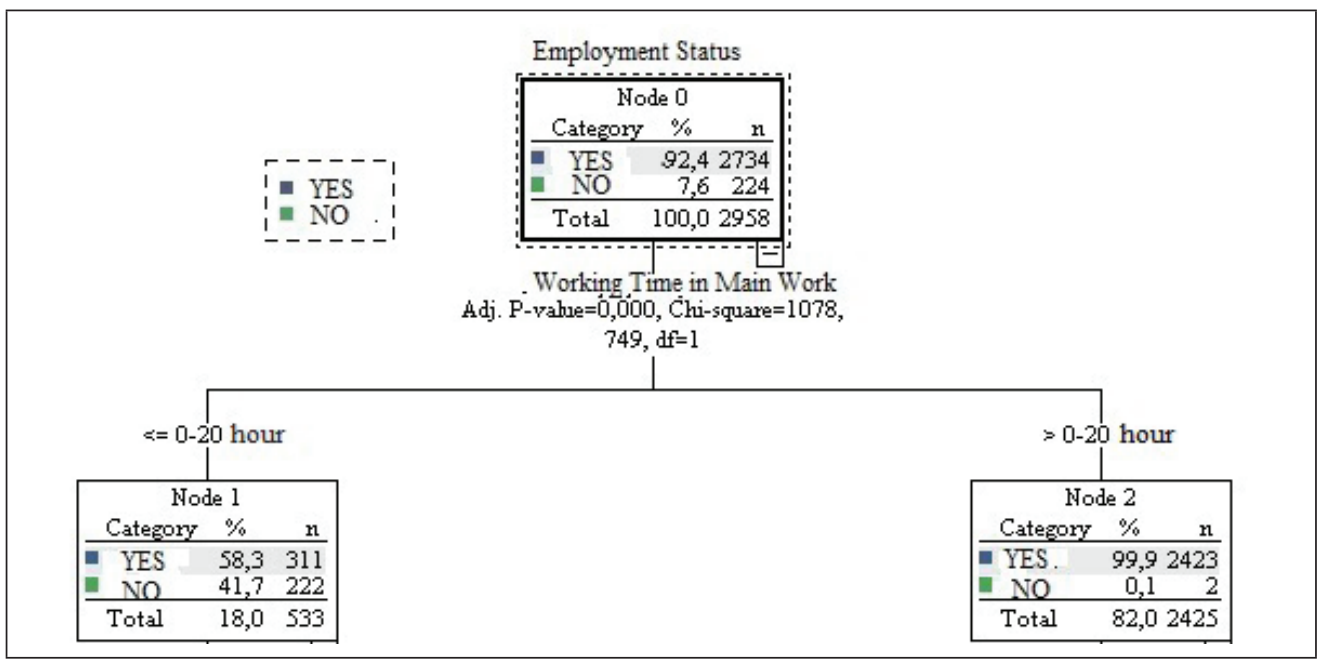

Working time over 20 hours affects female labour supply at a rate of $99.9 \%$. When working time is equal to or less than 20 hours, female labour supply decreases and occurs at a rate of $58.3 \%$. Accordingly, 2423 women want to supply their labour in case of working time equal to 20 hours and over. Additionally, 311 women want to offer their labour if working time is less than 20 hours. Under the condition of working time under 20 hours, the labour supply of female labour force is mostly affected by working type $(=239.025,=0.000,=1)$. This variable consists of two sub-clusters (i.e. full-time and part-time) with significant differences (Figure 3).

\section{Figure 3. Variables Affecting Female Labour in case of Working under 20 Hours}

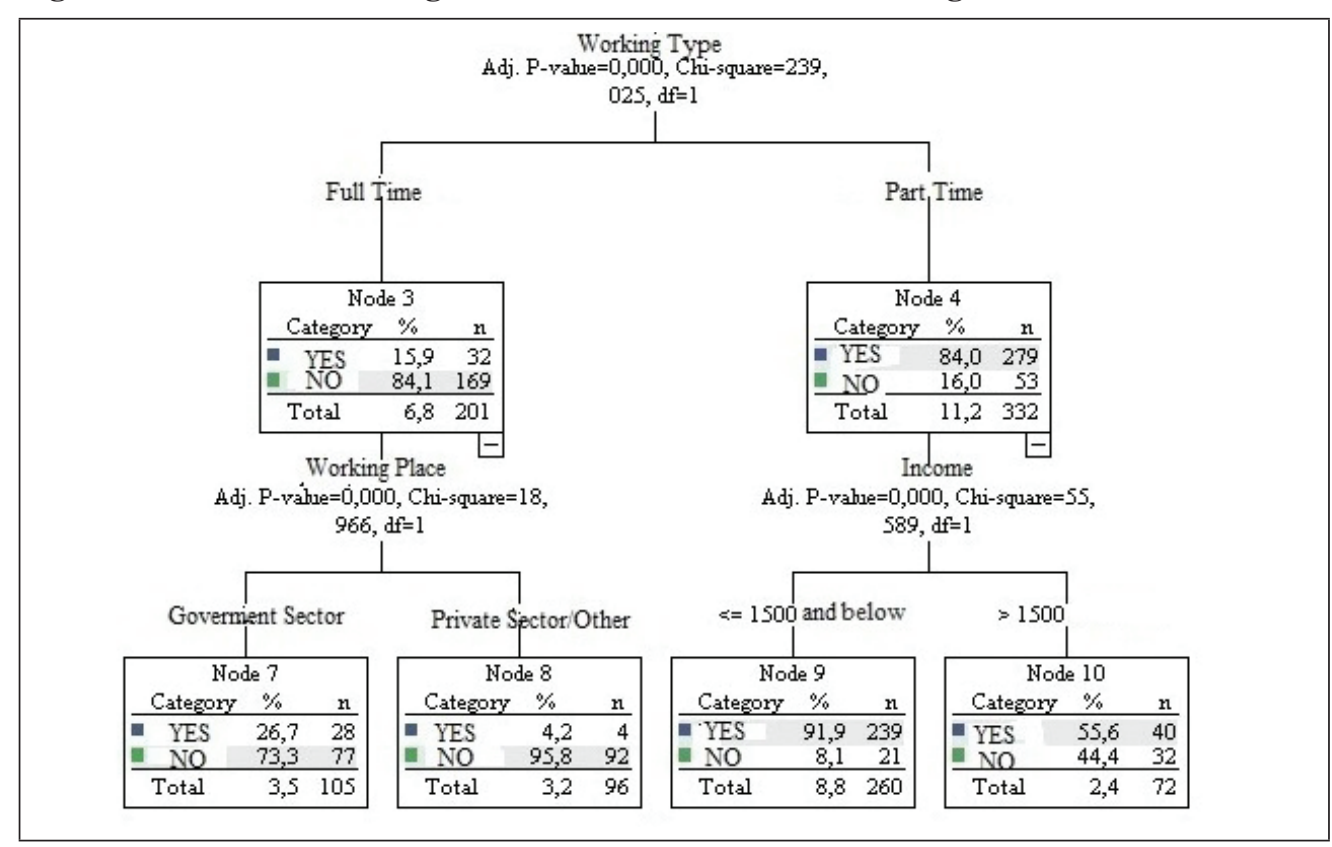


As seen in Figure 3, the rate of women who want to supply their labour full-time is 15.9 $\%$, the rate of those who do not want to supply their labour is $84.1 \%$. Considering the part-time working type, female labour supply rises to $84.1 \%$ and women who do not want to supply their labour falls to $15.9 \%$. The tree structure which branches into full-time and part-time according to working type further branches; thus, full-time work is affected by workplace $(=18,966$, $=0.000,=1)$ and part-time work is affected by income $(=55,589,=0.000,=1)$. Accordingly, women do not supply their labour full-time in the government, private and other sectors if working time is less than 20 hours. Women who want to supply their labour part-time under 20 hours decide depending on income. If the total household income is equal to or less than 1500 TRY, then $91.9 \%$ of the female labour force who accepts to work less than 20 hours are involved in the labour market. If the household income is more than 1500 TRY, the labour supply of the women in this group drops. This result suggests that household income has a decisive role in female labour supply. In case of working time under 20 hours and flexible working hours, the higher the household income is, the less likely women are to work in the service sector. In other words, women who want to work less than 20 hours or part-time prefer the substitution effect to the income effect as the household income increases. The most important factor determining the labour supply of women working less than 20 hours and full-time is workplace. Considering the nodes 7 and 8; women prefer to work less than 20 hours and full-time in the public sector rather than in the private sector.

The most decisive variable in the labour supply of women working over 20 hours is working type. The decisive variable that affects the labour supply of women working over 20 hours is educational level. The labour supply of women working more than 20 hours is affected by the $5^{\text {th }}, 6^{\text {th }}, 11^{\text {th }}$, and $12^{\text {th }}$ nodes in the $2^{\text {nd }}, 4^{\text {th }}$, and $7^{\text {th }}$ branches (Figure 4 ).

Figure 4. Variables Affecting Female Labour Supply in case of Working over 20 Hours

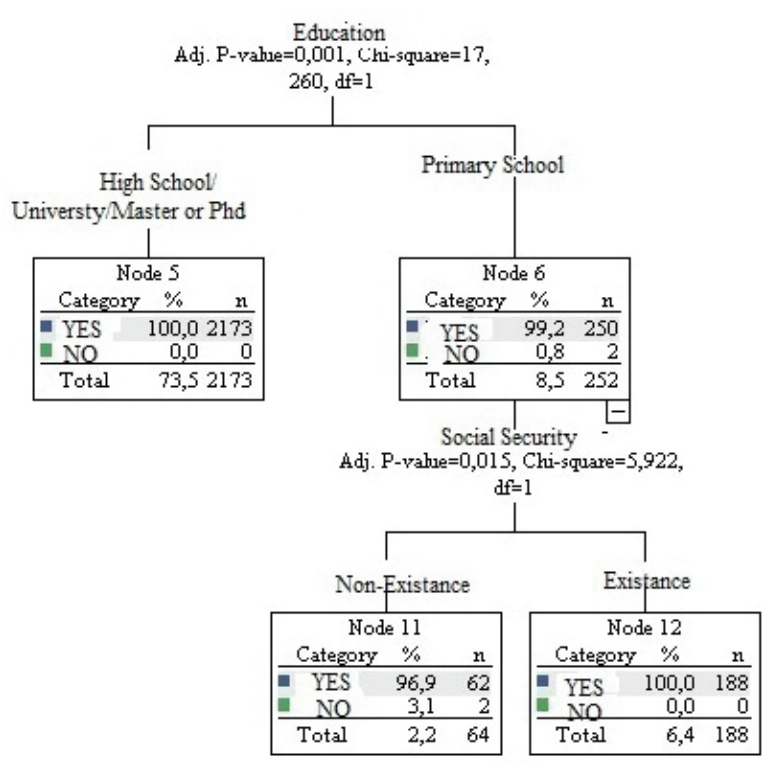


Considering the second node, the most important factor affecting the labour supply of women working over 20 hours is educational level $(=17,260,=0.000,=1)$. The level of education is also divided into two main branches that are primary education and other educational levels. $99.2 \%$ of the primary school graduates and $100 \%$ of the women with other educational levels in the working group are willing to employed in the labour market by working over 20 hours. While the existence of social security play a decisive role in the labour supply of women who are primary school graduates $(=5,922,=0.015,=1)$, there is no significant difference between having and not having social security. The existence of social security has a positive effect at a rate of $100 \%$ on the labour supply of primary school-graduate women, while the lack of social security has a negative effect at a rate of $3.1 \%$.

\section{Results and Discussion}

Labour supply is affected by many factors. Income and substitution are the primary factors. Each factor affects labour supply either positively or negatively. On the other hand, female labour supply is a complex concept as the determinants of female labour supply are more complex. Female labour supply in the service sector analyzed in this study is shaped by the effects of various the factors discussed above.

In this study, female labour supply was the dependent variable of the model for the service sector. The dependent variable was addressed under two categories as "yes" or "no" according to women's labour supply decision. All of the other variables which may affect labour supply were included in the study as independent variables. The CHAID analysis yielded a tree diagram composed of 7 branches and 12 nodes. The study showed that $92.4 \%$ of women want to supply their labour to the service sector and female labour supply in the sector is affected first by "working time in main job" and then by "working type", "education, "workplace", "income" and "social security". In a sense, nodes formed in the decision tree determines the variable's importance order in the CHAID analysis. Thus, the most effective explanatory variable for the dependent variable is the "working time in main job". Accordingly, working over 20 hours has a positive effect on female labour supply. Considering "working type" as the first of the seconddegree variables affecting labour supply, $84 \%$ of women who want to work less than 20 hours want to work part-time. The household income plays a decisive role in working of the women in this group (under 20 hours and part-time). If the total household income is over 1500 TRY, female labour supply decreases. Otherwise, female labour force supply increases. The labour supply of women who want to work full-time but under 20 hours varies depending on whether the workplace is a government or private sector. Women prefer to work in the government sector rather than in the private sector. This result stemmed from the perception that legal and social rights of the government sector are better than those of the private sector. Economic crises have greatly increased women's participation in the labour force. As a matter of fact, women are employed in low wage jobs through atypical employment contracts. As the results of this study indicate, the existence of social security is not decisive for the supply of female labour force who want to work over 20 hours, with the exception of those with primary education. Another significant variable that affects labour supply is the "level of education". Almost 100\% of women want to take part in working life, except for primary-school graduates. Analysing the service sector of the TR51 region, the study supports the results of the 2016 household labour force survey. According to the results of the survey, labour force participation rate shows that 
female participation in labour force increases as their level of education increases. The labour force participation rate of non-literate women is $15.2 \%$, the participation rate of high school and undereducated women is $27.2 \%$, the participation rate of high school-graduate women is $33.6 \%$, the participation rate of vocational or technical high school graduates is $41.4 \%$, the participation rate of women with higher education is $71.3 \%$. According to the economic field of activity, women are employed mostly in the service sector. As a matter of fact, $55.4 \%$ of service sector employment, which is at the rate of $53.7 \%$, is made up of women (TURKSTAT, 2018). The results of this study showed that working hours is decisive in labour supply. Accordingly, the substitution effect is important in the volume of labour provided to the service sector market by women entering the labour market for many reasons, such as economic needs of the household, changes in the social structure, level of education, and marital status. Women substitute leisure for work in the face of increased opportunity cost of leisure time and they increase labour supply. In other words, the monetary value of leisure time is rising. This situation leads to the fact that the substitution effect is greater than the income effect and the labour supply curve has a positive trend, as in the classical microeconomic theory. The reason for women's desire to work less than 20 hours and on a part-time basis can be attributed to the economic needs of household, and the desire for minimizing expenses that the household will pay for services such as food, cleaning and childcare. On the other hand, it is significant to mention that parttime employment is largely an unregistered employment form in Turkey, hence, most women in part-time employment are deprived of social security in the country. Women prefer public institutions as workplaces. The underlying reasons include the idea of not being unemployed after a long-term leave such as pre-natal, post-natal and breastfeeding leaves entitled to women by virtue of law. This result may be derived from the transaction demand for money. Based on the results of the study, it seems that educational level is not very effective on labour supply in case of working over 20 hours and primary-school graduates prefer social security to guarantee their health expenditures and retirement. Last but not least, a CHAID analysis proves useful for economic research as it is used in many fields. This statistical method allows for neutral and powerful results as it produces homogeneous nodes in heterogeneous data sets.

\section{References}

Akgeyik, T. (2017). Türkiye'de kadınların işgücü piyasasına katılımını etkileyen faktörler: TÜİK verileri üzerine bir analiz. Sosyal Siyaset Konferanslart Dergisi, 70 - 2016/1,31-53.

Argüden, Y., \& Y1lmaz, B. (2008). Veri madenciliği veriden bilgiye, masraftan de ğere. 1. Press. Istanbul: ARGE Consulting Publications.

Ashenfelter, O., \& Heckman, J. (1974). The estimation of income and substitution effects in a model of family labour supply. Econometrica, 42(1), 73-85.

Assael, H. (1970). Segmenting markets by group purchasing behavior: An application of the AID technique. J. Marketing Research, 7(2), 153-158.

Attanasio, O., Low, H., \& Snaches-Marcos, V. (2005). Female labour supply as insurance against idiosyncratic risk. Journal of the European Economic Association, 3(2/3), Papers and Proceedings of the Nineteenth Annual Congress of the European Economic Association (Apr. - May 2005), 755-764.

Ayvaz-Kızılgöl,Ö. (2012). Kadınların işgücüne katılımının belirleyicileri: Ekonometrik bir analiz. Doğuş Üniversitesi Dergisi, 13 (1), 88-101.

Blau, F. D., \& Kahn, M. L. (2013). Female labour supply: Why is the United States falling behind?. American Economic Review: Papers \& Proceedings, 103(3), 251-256. 
Bloom, E. D., Canning, D., Fink, G., \& Finlay J. E. (2009). Fertility, female labour force participation, and the demographic dividend. Journal of Economic Growth, 14(2), 79-101.

Breiman, L., Friedman, J. H., Olshen, R. A., \& Stone, C. J. (1984). Classification and regression trees. USA: CRS Press.

Buchmueller, T. C., \& Valletta, R. G. 1999. The effect of health insurance on married female labour supply. The Journal of Human Resources, 34(1), $42-70$.

Cahuc, P., \& Zylbereg, A. (2001). Labour economics. London: The MIT Press, Cambridge.

Cerruti, M. (2000). Economic reform, structural adjustment and female labour force participation in Buenos Aires, Argentina. World Development, 28(5), 879-891.

Chamlou, N., Muzi, S., \& Ahmed, H. (2011). Understanding the determinants of female labour force participation in the Middle East and North Africa region: The role of education and social norms in Amman. Almalaurea Working Papers, 31, September.

Chang, M. K., \& Man Law, S. P. (2008). Factor structure for young's internet addiction test: A confirmatory study. Computers in Human Behavior, 24(6), 2597-2619.

Chen, M. Y. (2011). Predicting corporate financial distress based on integration of decision tree classification and logistic regression. Expert Systems with Applications, 38, 11261-11272.

Cipollone, A., Patacchini, E., \& Vallanti, G. (2012). Women's labour market performance in Europe, trends and shaping factors. CEPS Special Report No: 66, Brussels.

Conover, W. J. (1971). Practical nonparametric statistics. New York: Wiley.

Cruces, G., \& Galiani, S. (2007). Fertility and female labour supply in Latin America: New causal evidence. Labour Economics, 14 (2007), 565 - 573.

Dayığlu, M., \& Kırdar, M. G. (2010). Determinants of and trends in labour force participation of women in Turkey. SPO\&WB Working Paper No:5, Ankara.

Eckstein, Z., \& Lifshitz, O. (2011). Dynamic female labour supply. Econometrica, 79(6), 1675-1726.

Er, Ş . (2013). Türkiye'de kadınların işgücüne katılım oranını etkileyen faktörlerin bölgesel analizi. Öneri, 10(40), 35-44.

Ettner, S. (1995). The impact of "parent care" on female labour supply decisions. Demography, 32(1).

Gift, M. (2013). Determinants of female labour force participation in Zimbabwe: 1980 To 2012 (Master Thesis). University of Zimbabwe.

Gorunescu, F. (2011). Data mining, concepts, models and techniques. Romania: Springer-Heidelberg, Intelligent Systems Reference Library.

İnce, M., \& Demir, M. H. (2006). The determinants of female labour force: Empirical evidence from Turkey. Eskişehir Osman Gazi Üniversitesi İ̈BF Dergisi, 1(1), 71-91.

Jaumotte, F. (2003). Female labour force participation: past trends and main determinants in OECD countries. Economic Department Working Papers No.376, OECD.

Kass, G. V. (1980). An exploratory technique for investigating large quantities of categorical data. Applied Statistics, 29(2), 119-127.

Kayri, M., \& Boysan, M. (2007). Araştırmalarda CHAID analizinin kullanımı ve baş etme stratejileri ile ilgili bir uygulama. Ankara University Journal of Educational Sciences, 40(2), 135-151.

Killingsworth, M. R., \& Heckman, J. J. (1986). Handbook of labour economics. Chapter 2 Female labour supply: A survey. 1, 103-204.

KILM. (2017). Key indicators of the labour market. 9th Ed. ILO.

Kimball, M. S., \& Sphapiro, M. D. (2008). Labour supply: Are the income and substitution effects both large or both small? NBER Working Paper No. 14208. 
Magidson, J. (1993). The use of the new ordinal algorithm in CHAID to target profitable segments. The Journal of Database Marketing. 1, 29-48.

Mincer, J. (1962). Labour force participation of married women: A study of labour supply. Aspects of Labour Economics, Princeton University Press.

Nisbet, R., Elder, J. F., \& Miner, G. (2009). Handbook of statistical analysis and data mining applications. Amsterdam: Elsevier.

OECD. (2017). https://stats.oecd.org/Index.aspx?DataSetCode=LFS_SEXAGE_I_R Retrieved Octorber $3,2017$.

Özekes, S. (2003). Veri madenciliği modelleri ve uygulama alanları. Istanbul Commerce University Journal. 3(3), 65-82.

Ritschard, G. (2013). CHAID and earlier supervised tree methods. In J. J. McArdle, G. Ritschard (Eds.), Contemporary issues in exploratory data mining in behavioral sciences. New York: Routeledge.

Seifert, J. W. (2004). Data mining: an overview. In D. D. Pegarkov (Eds.), National security issues. (pp. 201-217). New York: Nova Science Publishers Inc.

Shi, Y. (2016). What drives females' labour force participation in China? A study comparing urban and rural area (Master Thesis). Georgetown University, Washington.

Sorsa, P., Mares, J., Didier, M., Guimaraes, C., Rabate, M., Tang, G., \& Tuske, A. (2015). Determinants of the low female labour force participation in India. OECD Working Paper. No:1207, Paris, France.

Spierings, N., Smits, J., \& Verloo, M. (2008). Micro and macro-level determinants of women's employment in six MENA countries. NICE Working Paper 08-104, Netherlands.

Tansel, A. (2002). Economic development and female labor force participation in Turkey: Time-series evidence and cross-section estimate. METU/ERC Working Paper No. 02/3.

Taşseven, Ö., Altaş, D., \& Ün, T. (2016). The determinants of female labour force participation for OECD countries. International Economic Research Journal, 2(2), 27-38.

Tunalı, H., \& Göksu, Y. D. (2018). Türkiye'de kadınların işgücüne katılımının belirleyicileri üzerine ekonometrik bir analiz. Uluslararası Ekonomik Araştırmalar Dergisi, 4(1), 29-45.

TURKSTAT. (2018). İstatistiklerle kadın, 2017. News bulletin. Retrieved August 3, 2018 from http:// www.tuik.gov.tr/PreHaberBultenleri.do?id=27594

TURKSTAT. (2017). https://biruni.tuik.gov.tr/isgucuapp/isgucu.zul. Retrieved October 3, 2017.

Üngüren,E., \& Doğan,H. (2010). Beş yıldızlı konaklama işletmelerinde çalışanların iş tatmin düzeylerinin CHAID analiz yöntemiyle değerlendirilmesi. Cumhuriyet Üniversitesi İktisadi ve İdari Bilimler Fakültesi Dergisi, 11, 39-52.

Uysal, D., Keskin, R., \& Sertkaya, Y. (2016). Türkiye' de kadınların işgücüne katılmını belirleyen faktörler üzerine ekonometrik bir analiz. Siirt Üniversitesi İktisadi ve İdari Bilimler Fakültesi İktisadi Yenilik Dergisi, 3(2), 73-92.

Wilkinson, L. (1979). Tests of significance in stepwise regression. Psychological bulletin. 86, 168-174.

Yakubu, Y. A. (2010). Factors influencing female labour force participation in South Africa in 2008. The African Statistical Journal. 11, 85-104.

Yıldırım, K., Karaman, D., \& Taşdemir, M. (2010). Makro ekonomi. Ankara: Seçkin Yayıncılık.

Yohannes, Y., \& Webb, P. (1999). Classification and regression trees, cart: A user manual for identifying indicators of vulnerability to famine and chronic food insecurity. Microcomputers in policy research 3, Washington: International Food Policy Research Institute. 